\title{
INTERSECTION OF TECHNOLOGICAL SKILLS AND STRATEGIC COMPETENCES IN DEVELOPING THE HUMAN RESOURCE POLICY IN CONTEMPORARY RUSSIA
}

\author{
Aleksey Baranov ${ }^{1}$, Mikhail Ovakimyan $^{2}$, Olga Kotlyarova $^{3}$
}

\begin{abstract}
This article provides the results of research and projection of the current and innovative models of competences for modern civil servants. The principal aim of the study is to identify the interdependence of the human resource policy instruments and the current and innovative models of competences for a modern civil servant. The study objectives are fourfold: 1) describe the existing three-cluster competence model of a civil servant; 2) identify competences that update the professional potential of modern civil servants; 3) project an innovative model for a modern civil servant based on the results of a foresight analysis involving sessions with representatives of the state administration in the Rostov and Vladimir regions; and 4) identify the digital economy factors influencing the development of the civil service system in modern Russia. The methodological basis of this work is a large-scale foresight analysis using an expert survey carried out among representatives of the state administration of the Rostov and Vladimir region. This includes data analysis and classification of 302 individual questionnaires. The main purpose of the work is to identify the interdependence of strategic competences and technological skills for determining the dynamics of the Russian state human resource policy, as well as defining digital economy factors influencing the development of the civil service system in modern Russia.
\end{abstract}

JEL Classification: O15; DOI: 10.12955/cbup.v6.1125

Keywords: competence transformation, technological skills and strategic competence approach, a tool of updating a human resource policy, digital economy.

\section{Introduction}

The forming of a competitive human resource potential for public administration appears to be a strategic goal of modern Russia. Maintaining human resources is a priority for the development of society in general, and the system of public administration, in particular. Thus, improving the competence of a state and municipal civil servant, as well as expanding and actualizing the tools for an effective human resource policy, is integral for developing the system of state and municipal administration. The impossibility of ignoring the rapid development of the digital economy and the resulting global trends necessitates a keen focus on the dynamics of public administration in the information and technological space.

Most scholars agree on the need for a new personnel base, designed for public and municipal authorities.

The human resource factor in the system of public and municipal administration ensures resolution of a range of issues. They are related to social and economic development and satisfaction of the needs of the population in the territories. This involves high-quality public services and functions, which today requires the use of modern information technologies. In this regard, most scientists support the idea of accelerating technical and economic development, globalization, and the internationalization of innovative technologies (Tartakovskaya, 2011).

Scientific and practical interest in the new challenges in developing the human resource capacity of public and municipal authorities is supported by the works of Aganbegyan (2013), Agranovich (2003), Bartsits (1999; 2000), Bidzhiev (2014), Velikhov (1995), and Zaborovskaya (2015) among others.

The aim of this study is to identify the interdependence of the human resource policy instruments and the innovative models of competences required by a modern civil servant. This study has four main objectives: 1) Describe the existing three-cluster competence model of a civil servant; 2) Identify competences that update the professional potential of modern civil servants; 3) Project an innovative model for the modern civil servant, based on the results of a foresight analysis using sessions with

\footnotetext{
${ }^{1}$ Russian Presidential Academy of National Economy and Public Administration, Rostov-on-Don, a.v.baranov@uriu.ranepa.ru

${ }^{2}$ Russian Presidential Academy of National Economy and Public Administration, Rostov-on-Don, ovakimyan-m.a@mail.ru

${ }^{3}$ Department of Humanities and Social Sciences, the Russian Presidential Academy of National Economy and Public Administration, Vladimir, olya-apriori@yandex.ru
} 
representatives of the state administration of the Rostov and Vladimir regions; and 4) Identify the digital economy factors influencing the development of the civil service system in modern Russia.

Such a study is relevant because it provides an innovative competence model for civil servants of the Russian Federation. It also avails tools to update the state human resource policy in the paradigm of world experience and identifies the dynamic factors of the digital economy impact on developing the civil service system in modern Russia.

\section{Data and Methodology}

In 2016-2018 the authors conducted a bilateral regional study involving a large-scale foresight analysis and an expert survey of the state administration representatives in the Rostov and Vladimir regions. The survey involved 302 civil servants.

The foresight analysis was considered the most convenient and effective method for this research. It provided an opportunity to identify the competence needs of representatives of government authorities as determined by the civil servants themselves, the expert staff for the personnel policy of the Rostov and Vladimir regions, and the heads of structural subdivisions of the government bodies.

The most detailed method of foresight analysis is given in the study of the municipal service of Sivonen and Pouru (2014).

The projection of an innovative competence model involved the indirect and direct participation of representatives of the Council on Civil Service of the Rostov Region under the Governor of the Rostov Region, the Personnel Department of the government of the Rostov Region, and the human resources services of the structural units of the government of the Rostov Region. It also involved civil servants of various structural units of the Administration of the Vladimir Region.

\section{Results and Discussion}

The study identified eight competences of civil servants as the most significant of those considered traditionally important. These were the ability to manage change, creativity, flexibility, futureorientated thinking, innovative, ability to build relationships, showing foresight, and displaying a readiness to cooperate (ability to negotiate).

Based on the analysis of the survey, the current model of competences for state and municipal civil servants was determined (Table 1) with three general clusters each involving specific conceptual qualities.

The competence model needs to be changeable in the paradigm of a dynamic reality. Hence, the main characteristic of this competence model is flexibility.

The outcomes of the large-scale rapid foresight analysis and generalization of the expert survey conducted in this study provided an innovative model of competences for the modern state and municipal civil servants of the Russian Federation (Table 2).

Table 1. Clusters and conceptual qualities of the current competence model for a contemporary civil servant

\begin{tabular}{|c|c|c|c|c|}
\hline Clusters & \multicolumn{4}{|c|}{ Conceptual Qualities } \\
\hline $\begin{array}{l}\text { 1. Compliance } \\
\text { with the } \\
\text { culture of the } \\
\text { civil service }\end{array}$ & $\begin{array}{l}\text { Professional } \\
\text { motivation. Ambition } \\
\text { for professional self- } \\
\text { realization in the civil } \\
\text { service, orientation to } \\
\text { career growth in } \\
\text { public administration. }\end{array}$ & $\begin{array}{l}\text { Civic position. } \\
\text { Following the } \\
\text { principles of } \\
\text { service to society } \\
\text { and the state, } \\
\text { compliance with } \\
\text { the law, rules of } \\
\text { service ethics. }\end{array}$ & $\begin{array}{l}\text { Activity of the } \\
\text { professional } \\
\text { position. Ambition } \\
\text { for taking the } \\
\text { initiative when } \\
\text { solving all of the } \\
\text { set objectives, } \\
\text { readiness to make } \\
\text { considerable efforts } \\
\text { to achieve the best } \\
\text { result, ability to } \\
\text { effectively act in } \\
\text { the context of } \\
\text { physical and } \\
\text { emotional burden. }\end{array}$ & $\begin{array}{l}\text { Readiness for } \\
\text { personal } \\
\text { development. A } \\
\text { constant desire to } \\
\text { improve personal } \\
\text { knowledge, } \\
\text { abilities, and skills, } \\
\text { broaden an } \\
\text { outlook, acquire } \\
\text { knowledge and } \\
\text { experience in } \\
\text { related professional } \\
\text { fields. }\end{array}$ \\
\hline
\end{tabular}




\begin{tabular}{|c|c|c|c|}
\hline $\begin{array}{l}\text { 2. Professional } \\
\text { competence of } \\
\text { a civil servant }\end{array}$ & $\begin{array}{l}\text { Professional } \\
\text { experience. Duration } \\
\text { and peculiarities of } \\
\text { activities in the } \\
\text { relevant professional } \\
\text { sphere; achievement } \\
\text { of concrete results in } \\
\text { professional activities; } \\
\text { peculiarities of a } \\
\text { career. }\end{array}$ & $\begin{array}{l}\text { Specific } \\
\text { professional } \\
\text { knowledge, } \\
\text { abilities, and skills. } \\
\text { The level of } \\
\text { professional } \\
\text { knowledge in the } \\
\text { corresponding } \\
\text { sphere which } \\
\text { allows performing } \\
\text { the functions } \\
\text { effectively; } \\
\text { knowledge of } \\
\text { legislation of the } \\
\text { Russian Federation } \\
\text { regulating } \\
\text { professional } \\
\text { activity; knowledge } \\
\text { of contemporary } \\
\text { information and } \\
\text { communication } \\
\text { technologies. }\end{array}$ & $\begin{array}{l}\text { General technology } \\
\text { skills. The level of } \\
\text { proficiency in skills } \\
\text { that increase the } \\
\text { overall } \\
\text { effectiveness of } \\
\text { professional } \\
\text { activities (computer } \\
\text { skills, knowledge } \\
\text { of foreign } \\
\text { languages). }\end{array}$ \\
\hline $\begin{array}{l}\text { 3. Personal } \\
\text { business } \\
\text { qualities }\end{array}$ & $\begin{array}{l}\text { Effective } \\
\text { communication skills. } \\
\text { Compliance with the } \\
\text { ethics of business } \\
\text { communication, the } \\
\text { ability to defend a } \\
\text { personal point of view } \\
\text { providing arguments } \\
\text { and convince } \\
\text { opponents, mastering } \\
\text { the skills of } \\
\text { conducting business } \\
\text { negotiations. }\end{array}$ & $\begin{array}{l}\text { Responsibility. } \\
\text { Substantiation and } \\
\text { independence in } \\
\text { decision-making, } \\
\text { readiness to follow } \\
\text { the obligations } \\
\text { undertaken in } \\
\text { achieving the } \\
\text { result. }\end{array}$ & $\begin{array}{l}\text { Organizational } \\
\text { skills. Ability to } \\
\text { achieve the result } \\
\text { by means of the } \\
\text { effective planning } \\
\text { of personal activity } \\
\text { to set tasks and } \\
\text { distribute functions } \\
\text { and responsibilities. }\end{array}$ \\
\hline
\end{tabular}

Table 2. Clusters and conceptual qualities of the innovative competence model for contemporary state and municipal civil servants of the Russian Federation

\begin{tabular}{|c|c|c|c|c|}
\hline Clusters & \multicolumn{4}{|c|}{ Conceptual Qualities } \\
\hline $\begin{array}{l}\text { 1. System } \\
\text { management }\end{array}$ & $\begin{array}{l}\text { A vision of the } \\
\text { future }\end{array}$ & $\begin{array}{l}\text { Management by } \\
\text { objectives }\end{array}$ & $\begin{array}{l}\text { Trade unions } \\
\text { establishment }\end{array}$ & Leadership \\
\hline 2. Problem-solving & $\begin{array}{l}\text { Information } \\
\text { analysis }\end{array}$ & $\begin{array}{l}\text { Alternatives } \\
\text { formation }\end{array}$ & $\begin{array}{l}\text { Conceptual } \\
\text { flexibility }\end{array}$ & Decision-making \\
\hline $\begin{array}{l}\text { 3. Interpersonal } \\
\text { relationships }\end{array}$ & Ability to hear & $\begin{array}{l}\text { Understanding the } \\
\text { reaction of others }\end{array}$ & Behavior flexibility & $\begin{array}{l}\text { Assistance to } \\
\text { employees in } \\
\text { professional } \\
\text { development }\end{array}$ \\
\hline $\begin{array}{l}\text { 4. Operational } \\
\text { effectiveness }\end{array}$ & Initiative & Operational control & $\begin{array}{l}\text { Delegation of } \\
\text { authority }\end{array}$ & $\begin{array}{l}\text { Ability to } \\
\text { concentrate }\end{array}$ \\
\hline $\begin{array}{l}\text { 5. Impact on } \\
\text { people }\end{array}$ & Oral presentations & Self-confidence & Ability to persuade & $\begin{array}{l}\text { Development of an } \\
\text { action plan }\end{array}$ \\
\hline $\begin{array}{l}\text { 6. Personal } \\
\text { qualities }\end{array}$ & Energy & Resistance to stress & $\begin{array}{l}\text { Motivation for } \\
\text { quality work }\end{array}$ & Ability to study \\
\hline $\begin{array}{l}\text { 7. Governance } \\
\text { considering the } \\
\text { environment }\end{array}$ & $\begin{array}{l}\text { Perception of } \\
\text { external } \\
\text { environment }\end{array}$ & $\begin{array}{l}\text { Understanding of } \\
\text { political factors }\end{array}$ & Honesty and ethics & $\begin{array}{l}\text { Awareness of the } \\
\text { personal role }\end{array}$ \\
\hline
\end{tabular}


The conceptual qualities of the main competence clusters were orientated towards creating value in the system of public service in the Russian Federation.

The presented competence model was created to cover the main range of tasks of the state and municipal service development. The design and dynamics of the presented model were aimed at saving human resources in the system of public and municipal administration.

The range of the main tasks covered by the new competence model is shown in Figure 1.

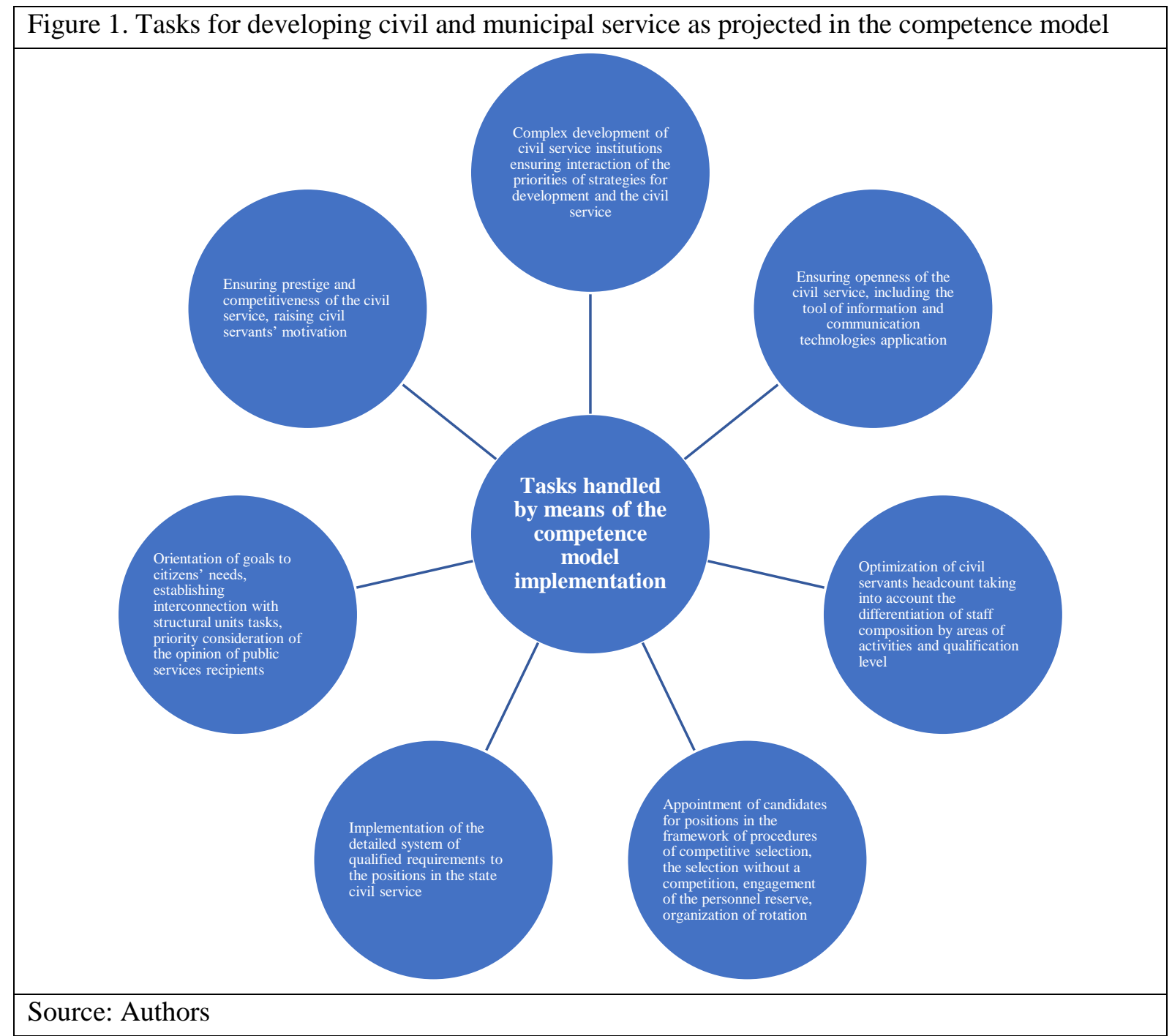

The formation of the innovative model of competences for civil servants was based on the results of the regional study of 40 personnel divisions within the government of the Rostov Region. These results, based on the survey of experts, are shown in Figures $2-4$.

The experts identified key professional competences for a civil servant (Figure 2), the specifics of which depended on the social status, the age, experience, and professional development of the official.

\begin{tabular}{|c|c|c|c|}
\hline \multicolumn{4}{|c|}{$\begin{array}{c}\text { Key professional } \\
\text { competences of a } \\
\text { civil servant }\end{array}$} \\
\hline $\begin{array}{c}\text { Work with } \\
\text { enactments } 35,0 \%\end{array}$ & $\begin{array}{c}\text { Activity planning } \\
37,5 \%\end{array}$ & Team work $37,5 \%$ & $\begin{array}{c}\text { Managerial } \\
\text { decision-making } \\
42,5 \%\end{array}$ \\
\hline
\end{tabular}


The experts participating in the survey identified the following key managerial competences for a civil servant: ability to think strategically for long-term planning and strategic management, display legal literacy, perform managerial decisions, and show a readiness to adapt to changes (Figure 3).

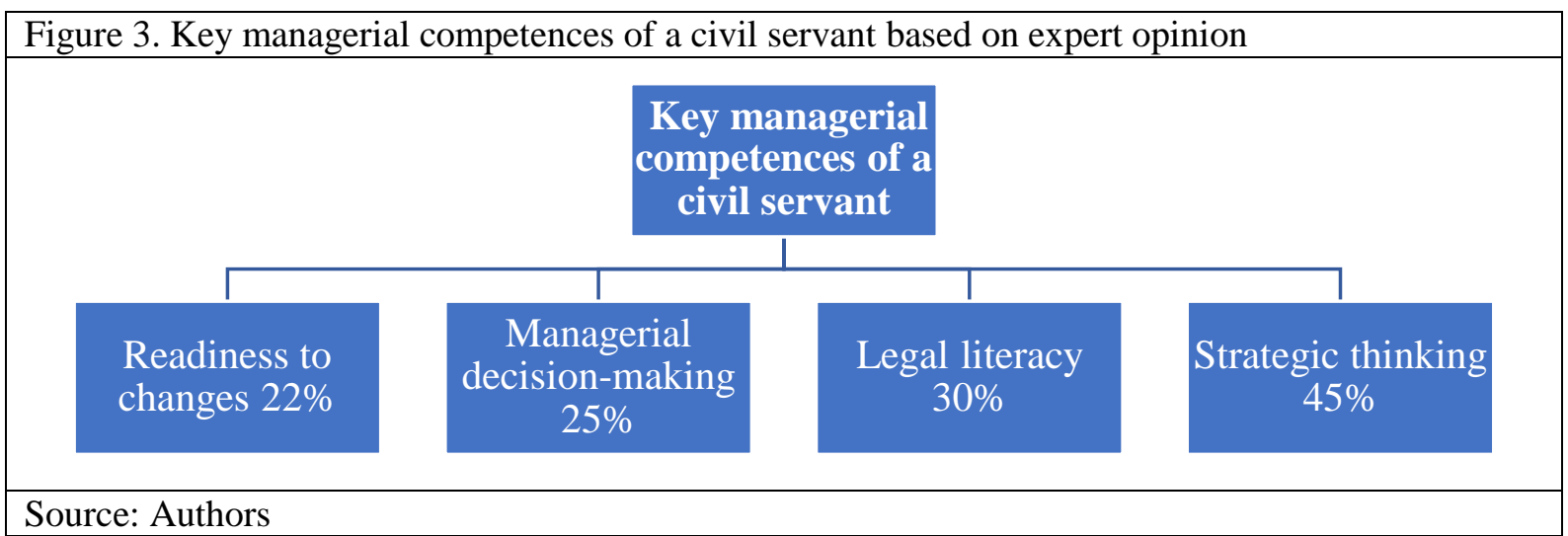

The experts also identified four main personal business competences for the civil servant: responsibility, sociability, decency, and resilience (Figure 4).

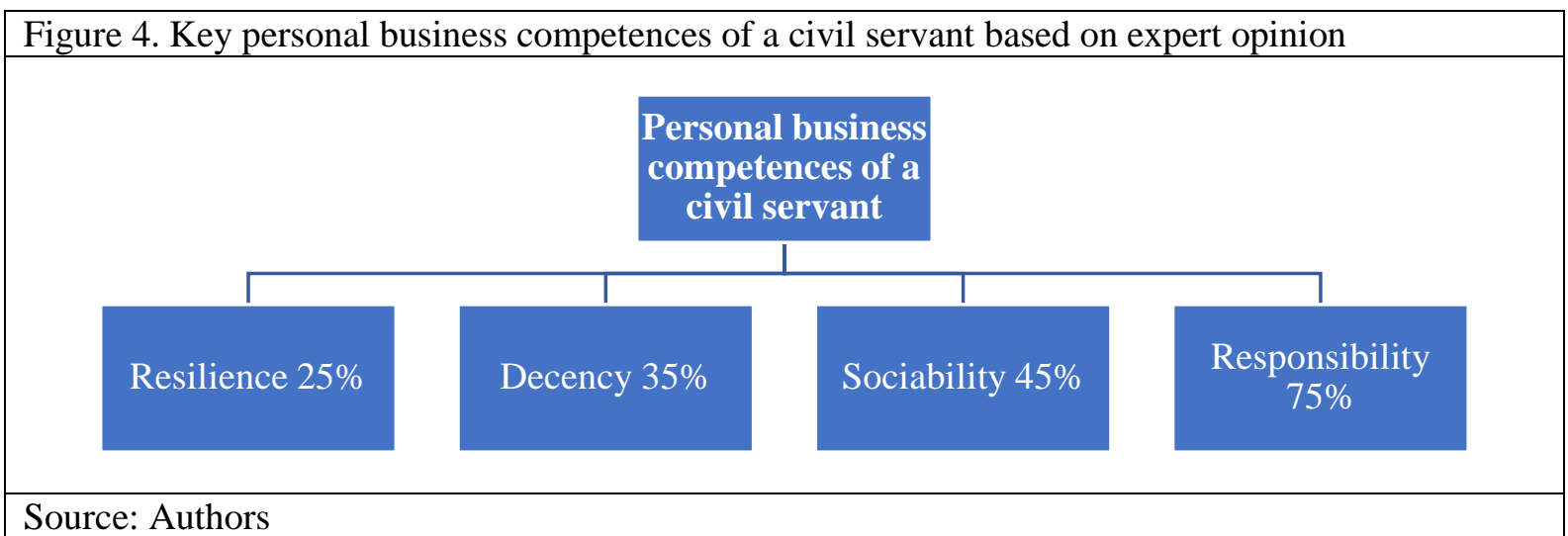

The study of the opportunities and dynamics of the human resource policy relating to public administration in Russia cannot be confined to the strategic competences alone. This is because strategic competences are mutually dependent on technological skills, which are about the use of basic technologies and tools for developing the state human resources.

Regarding the tools for updating the state human resource policy in the paradigm of world experience, the Russian Presidential Academy of National Economy and Public Administration developed a concept for staffing the public administration. This approach aimed to improve the work of human resources in state and municipal authorities and state organizations by means of introducing modern human resources technologies (The Concept of staffing of the system of public administration, 2017).

The key proposals for updating the state human resource policy, its regarding the modern design of tools for the staff of public administration included five basic factors.

First, the planning of work with personnel would act as an integral system (of an integrated personnel cycle). In the long term, this should improve the management of personnel by providing employees of different structures with the same opportunities for self-realization.

An integrated system of personnel management introduces technology that would transform the competences into requirements of the positions. This would use formalized and regular assessment procedures and a transparent measurement system in place of the formal certification procedure to rate the performance of employees. The technology would also use a regulation for possible dismissal from the state civil and municipal service for inefficiency or non-compliance with ethical conduct, modernize the wage system, a unified system of reserves for administrative personnel on the basis of general methodological principles and assessing the potential of the 'talent pool' for the public administration. It would also involve regular activities to develop the organizational culture and increase the attractiveness of the public administration system. It can be achieved by correlating the 
results of activities with changes in the perception of the population regarding their satisfaction with the quality of public services.

The second is to form models for staffing public or municipal authorities that have an intake option open to many applicants from the market for positions including managerial, and another that is closed and conditioned for hiring applicants from the market for the lowermost positions in the system.

The third factor is the clear division of the state and municipal civil service and its supporting processes.

The fourth is the optimization of the labor organization in the public administration system, which would introduce methods for calculating the optimal number of personnel interdependent with the volume of functions performed and by means of the information and communication technologies implemented. The number of state civil servants would be based on recommendations for its rationing as per the public and municipal administration (Rudoj \& Ovakimyan, 2014).

The fifth is having the personnel to ensure the organizational and methodological unity of work.

The latter point is indirectly related to the problems of training, upgrading of skills, and retraining of the civil service personnel.

The educational paradigm defines the leading trends that determine all aspects of training, development, and self-development of civil servants. These tendencies include, above all, recognition and maintenance of the priority of education in the development of state and municipal government.

World renown scientists from Germany, Japan, Great Britain, and the United States (US) agree that the provision of opportunities for continuing education can be considered as the actual aspect of the development of the human resources potential of civil servants (e.g., Nabiev, 2017).

The state human resource policy of Japan, the Republic of Korea and China regulates the popular and, what is most important, comfortable, convenient education in demand for civil servants (e.g., Baranov et al., 2016). The timeliness system uses certain stages corresponding to obtaining a supplementary education at each level of career development. Convenience and comfort are achieved by using innovative educational technologies.

In this regard, the tools for actualizing the personnel policy include electronic training and a system of massive open online courses (MOOC).

MOOC in the public administration system are an innovative global educational trend. Despite the resistance of the Russian education system in applying most online content, the introduction of MOOC can be argued by the versatility of the service and its availability. The positive factors include the possibility of teaching to an unlimited number of listeners at any time in an accessible place (anywhere in the world) that is convenient for them.

The use of e-learning, innovative, and non-standard methods of teaching can be referred to as motivational tools for actualizing the development of human resource policy in the educational paradigm. An example of such methodologies is where social learning occurs from the dynamic unilateral transfer of knowledge to bilateral interactive understanding by means of communication and cooperation, or the application of an inverted learning methodology based on transforming the traditional structure of education.

The need for the competent implementation of supplementary vocational education is generally recognized in most developed countries. Despite the fact that the Russian system of supplementary vocational education lacks clear regulated standards, the leading universities of the country, primarily the Russian Presidential Academy of National Economy and Public Administration, conduct largescale research to improve the quality and effectiveness of additional professional programs for upgrading skills and professional retraining (Markvart, 2016).

The system of targeted, planned, and stable monitoring, that of assessing the competences as opportunities for civil servants, needs tools to actualize the state of the human resource policy of the Russian Federation, as well as that of the US, Germany, Great Britain, Japan, China, and the Czech Republic.

The evaluation of the competence developed in the personnel has potential to stimulate the representatives of the authorities to grow professionally and develop themselves. The analysis of professional opportunities helps to determine the strategic goals and objectives of public policy, and 
correctly calculate the necessary resources and possible risks. The measurement of the intellectual dynamics of modern civil servants, based on the intelligence quotient (IQ), and the behavioral strategies of government officials and other characteristics are important.

Communication competence as an evaluation performance indicator regulating intercultural interaction is of the greatest research interest according to the works of Brighton (2013), Sillars and Vangelisti (2006), and Kegeyan (2016) on communication competence of civil servants and the need to implement competent intercultural interaction.

According to some researchers, the public administration continually interacts with the political discourse and the media, which are tools for forming public opinion on politically important issues (Anatanesjan, 2009; Shteynman, 2016).

Based on the experience of Estonia, the Czech Republic, Great Britain, US, and Canada, it is necessary to refer a diverse system of motivating civil servants to the important tools of updating and increasing the effectiveness of the state human resource policy (Sheiman \& Shevskij, 2015). In addition to material motivation, there exists moral or intellectual motivation based on the interest of civil servants wanting to expand their worldview or obtain additional competences for their intellectual satisfaction. Such motivation is achieved through the provision of relevant and innovative educational content.

The global research community has long recognized mentoring in public administration as an effective tool for developing the human resource potential of civil servants (Zanina \& Morozova, 2010).

In summarizing the above, the authors consider it necessary to highlight the characteristics in updating the Russian state human resource policy. The overall implementation of professional development, the acquisition of supplementary education, and career growth are considered important.

Activities aimed at updating the Russian human resource policy would need to consider the mental characteristics of civil servants. The positive mental characteristics for a civil servant in Russia would include humanistic values, including a sensitive approach to family and friends, as well as the prestige of working in the civil service, understanding the importance of their duties, and having an awareness of their responsibility in the decision outcomes. It is important to identify negative national characteristics, which include: traditional 'disbelief' in the system of public and municipal administration, distrust of power, and inability and unwillingness to respect the chain of command.

Most researchers agree on the need to reform the development of the human resource policy of modern Russia. Today, the priorities of such development are oriented towards the potential value of the new generation, its spirituality, and the need to bring significant benefits to the nation and the state, and humanity as a whole. The introduction of the value management paradigm would need to contribute to the growth of the public administration as a performance indicator that determines the quality of state functions, services, state institutions, and the level of trust in the policy pursued by the authorities (Albastova \& Ovakimyan, 2017).

In investigating the question of whether to update the human resource policy of modern Russia and consider its determining factors, it is impossible to ignore the dynamics of the civil service in line with the development of the digital economy.

The digital economy influences the development of the civil service system of modern Russia. The recent research in the field of digitalization, in general, and the digital economy, in particular, indicates the digital economy is "the result of general-purpose transformation technologies in the field of information and communication" (OECD Digital Economy Outlook, 2015, p.63).

The digital economy covers all important spheres of state and municipal government and provides unlimited opportunities to avail new development prospects for the public administration.

The digital economy and innovative technologies, for example, in the field of natural resource management, allow the forecasting of natural changes, including variations in weather, prediction of environmental disasters, and monitoring of weather and global changes in nature conservation.

In the field of health, the digital economy provides technologies that enable people to measure health as quickly and accurately as possible to increase their life expectancy, reduce the risks of incurable diseases, and change genetic predispositions. 
The digital economy provides a qualitative revolution in modeling data of buildings and structures for the emergence of digital smart cities and regions in the field of construction.

Digitalization opportunities in the communication field provide analyses of hidden data and the forecasting of global political and economic situations and thus provide measured security for the state and citizens. The emergence of the Electronic State and the Electronic Government was predetermined by the possibility of digitizing documentation and using electronic signatures. This circumstance has expanded and accelerated the list of provisions of public services for citizens.

New innovative approaches to manage and accelerate the provision of public services are crucial for the public administration development.

The digital economy is innovative and includes innovations, in a broad sense, towards consumption and production, perception and interpretation of information, and life experiences and virtual realities.

The factors that determine the impact of the digital economy on the development of the civil service system of a modern Russia include the forecasting of immediate and long-term prospects for the development of the state.

It is important to identify the preservation of human resources and the creative potential of people as a positive aspect of the digital economy in the Russian public administration. This could involve implementing a labor-efficient policy, applying flexible schedules with a modern mobile and local system technologies, and electronic platforms that simplify navigation in public and private services.

The systemic nature of implementing digitalization in Russia is confirmed by the announcement of the national technical initiative, the use of tools and technologies the product lifecycle management system (PLM), business process management (BPM), and the building information model (BIM), among others.

However, with any innovation, there are potential risks. The digital economy focuses on the maximally profitable expenditure of resources. At the same time, the spiritual and ethical focus on developing society is subdued. Thus, there is a need to determine the boundaries of applying innovative technologies, the delineation of the material and value paradigm of modern society, and the consideration of the human factor.

The formation of a new model of competences for state civil servants is conditioned by their desire to work in a new way in the changed social and economic conditions and to solve problems in their territories promptly and qualitatively. At the same time, an insufficient base of theoretical knowledge and a lack of practical experience can impede task completion and the contribution by the reformers to the development of the country. As revealed in practice, the most successful managers are those who have experience and have undergone special training to develop their professional competences.

In introducing a new competence model, programs for the development of state civil servants are necessary. The programs of educational centers could be adjusted to include requirements, based on the opinion of the employer (or a representative of the employer), that improve the competences of center graduates and strengthen their practical orientation.

Along with the strategic competence approach, it is important to use other relevant approaches in forming a new model of competences for a civil servant. Solely owning these competences in the context of constant change does not guarantee the completion of atypical tasks. In such cases, as the research conducted by the authors shows, a better approach is to rely on a civil servant's swift assimilation of new technologies and abilities to find relevant and effective solutions.

In conclusion, it is necessary to emphasize that the transitioning to a digital economy has resulted in a huge shortage of qualified personnel in the sphere of public and municipal administration. Nevertheless, the growing importance of universities and the educational system, as a whole, where interdisciplinary personnel are formed, is encouraging in regards to forming a stable and efficient functioning of the public service system.

\section{Conclusion}

This study established the current competence model for civil servants and projected an innovative model of competences needed for a modern state servant in line with the development of the digital economy. The following are the three main study outcomes. First, the scientific and teaching staff of the Russian Presidential Academy of National Economy interacted with the Public Administration and 
representatives of the government bodies, aimed at with the aim of increasing the effectiveness of the state human resource policy. Second, the state civil servants who participated in the sessions for the foresight analysis displayed enhanced interest in developing their own competences. Third, the study findings support the continuation of a joint large-scale regional research. The authors aim to continue developing the dynamics of government officials' competences in future research that considers the development of the digital economy and the social importance of forecasting the human resource potential based on the state personnel policy in modern Russia.

\section{References}

Aganbegyan, A.G. (2013). On the lessons from the financial and social crisis in Russia. Problems of Theory and Practice of Management, 3.

Albastova, L.N., Ovakimyan, M.A. (2017). Management Theory. Rostov-on-Don: SRIM RANEPA, 344 p.

Agranovich, M. (2003). Higher education system of the region and sustainable development: an attempt of statistical analysis. Proceedings of the All-Russian scientific and practical seminar "Education and science as factors of sustainable development of the region", Tver, 101-108.

Baranov, A.V., Tagaev, A.V., Kotlyarova, O.V. (2016). The open education system in the Republic of Korea: prospects for implementation. Central Russian Journal of Social Sciences, 6.

Bartsits, I.N. (2000). The legal space of Russia: questions of constitutional theory and practice. Moscow: MSU Publishing House.

Bartsits, I.N. (1999). Federal responsibility: constitutional and legal aspects. Moscow: Publishing center of Plekhanov Russian University of Economics.

Bidzhiev, A.S. (2014). Methods of the personnel potential formation of municipal authorities in the context of municipal education development. Candidate's thesis abstract. Moscow, p. 385.

Velikhov, L.A. (1995). Fundamentals of urban economy. Obninsk, p.67.

Zaborovskaya, S. (2015). Human resource policy implementation in the system of public and municipal authorities. Civil service, 2(94).

Zanina, T.M., Morozova, I.S. (2010). Features of admission (enrollment) to the civil service in the UK police. The bulletin of Voronezh Institute of the Ministry of Internal Affairs of Russia, 2.

The Russian Presidential Academy of National Economy and Public Administration. (2017). The Concept of staffing of the system of public administration. (Online). Available at: http://intranet.ranepa.ru (Accessed 2 March 2012 ).

Markvart, E. (2016). Municipal authorities' competence - mutation in the course of another municipal reform. Problems of governance theory and practice, 5 .

Nabiev, V.V. About of foreign experience of reception to service and certification of state employees. The bulletin of Voronezh Institute of the Ministry of Internal Affairs of Russia, 1.

Rudoj, V.V., Ovakimyan, M.A. (2014). The number of state civil servants: recommendations for its rationing. Public and municipal administration. Scientific notes of SKAGS, 4.

Sheiman, M.M., Shevskij, V.I. (2015). Human resource policy in health: a comparative analysis of Russian and international practice. Public Administration Issues, 1.

Atanesian, A. (2009). Terrorism as a communication phenomenon Central Asia and the Caucasus, 143.

Brighton, C. (2013). Assessing intercultural Communicative competence. Pedagogical Education in, p. 201.

Kegeyan, S.E. (2016). Intercultural communication in the workplace and the role of communication in an organization. International Journal of Professional Science, 32.

OECD Digital Economy Outlook (2015). Paris: OECD Publishing, 284 p.

Sivonen, S., Pouru, L. (2014). Competence foresight in local government services KT Local government employers. Helsinki.

Sillars, A.L., Vangelisti, A.L. (2006). Communication: Basic properties and their relevance to relationship. New York Cambridge: Univercity Press, pp. 331-351.

Steynman, M. (2016). Political Myth and Political Glory: Shaping Media Reality. Sociological Review ARIA, 123. 